\title{
Stable reference genes for the measurement of transcript abundance during larval caste development in the honeybee
}

\author{
Rosannah C. CAmeron $^{1,2}$, Elizabeth J. DunCAN ${ }^{1,2}$, Peter K. Dearden ${ }^{1,2}$ \\ ${ }^{1}$ Laboratory for Evolution and Development, National Research Centre for Growth and Development and Genetics \\ Otago, Dunedin, New Zealand \\ ${ }^{2}$ Biochemistry Department, University of Otago, Dunedin, New Zealand
}

Received 12 July 2012 - Revised 11 November 2012 - Accepted 29 November 2012

\begin{abstract}
Many genes are differentially regulated by caste development in the honeybee. Identifying and understanding these differences is key to discovering the mechanisms underlying this process. To identify these gene expression differences requires robust methods to measure transcript abundance. RT-qPCR is currently the gold standard to measure gene expression, but requires stable reference genes to compare gene expression changes. Such reference genes have not been established for honeybee caste development. Here, we identify and test potential reference genes that have stable expression throughout larval development between the two female castes. In this study, 15 candidate reference genes were examined to identify the most stable reference genes. Three algorithms (GeNorm, Bestkeeper and NormFinder) were used to rank the candidate reference genes based on their stability between the castes throughout larval development. Of these genes Ndufa8 (the orthologue of a component of complex one of the mitochondrial electron transport chain) and Pros54 (orthologous to a component of the $26 \mathrm{~S}$ proteasome) were identified as being the most stable. When these two genes were used to normalise expression of two target genes (previously found to be differentially expressed between queen and worker larvae by microarray analysis) they were able to more accurately detect differential expression than two previously used reference genes (awd and RpL12). The identification of these novel reference genes will be of benefit to future studies of caste development in the honeybee.
\end{abstract}

caste development / larval development / gene expression

\section{INTRODUCTION}

Reverse transcription quantitative PCR (RTqPCR) is considered the gold standard for gene expression analysis (Bustin et al. 2009), due to its unrivalled sensitivity and ability to accurately quantify relative transcript numbers over a

Electronic supplementary material The online version of this article (doi:10.1007/s13592-012-0187-0) contains supplementary material, which is available to authorized users.

Corresponding author: P.K. Dearden, peter.dearden@otago.ac.nz

Manuscript editor: Klaus Hartfelder wide dynamic range (Valasek and Repa 2005). Relative quantification of gene expression using RT-qPCR requires robust, reliable reference genes to correct for technical variation within the experiment. Reference genes must retain stable expression between samples to allow the detection of subtle changes in transcript abundance, as fluctuations can skew the measurement of target gene expression. Finding adequate reference genes that meet these criteria is often difficult, especially in developmental studies where changes in cell numbers and ongoing patterning processes may have profound effects on gene expression. Current recommendations are that at least two reference 
genes that are stable in all samples should be used to achive robust expression measurement (Vandesompele et al. 2002). When using a single reference gene, errors of up to 20 -fold have been found to occur (Vandesompele et al. 2002).

Queen and worker honeybees (Apis mellifera) have markedly different physiology and behaviour in response to diet stimuli provided during larval development. These different diets result in differences in gene expression (Severson et al. 1989; Corona et al. 1999; Evans and Wheeler 1999, 2001; Wheeler et al. 2006; Barchuk et al. 2007; de Azevedo and Hartfelder 2008; Humann and Hartfelder 2011; Chen et al. 2012) and epigenetic modifications of the DNA (Kucharski et al. 2008), resulting in the development of the queen and worker adult castes. Several largescale studies of gene expression between queen and worker larvae have been performed using microarrays or RNAseq (Evans and Wheeler 2001; Barchuk et al. 2007; Chen et al. 2012). While studies using microarrays are valuable as they interrogate expression of thousands of genes simultaneously, they are also prone to falsepositive results (Okoniewski and Miller 2006), and require validation with other techniques such as RT-qPCR (Evans and Wheeler 2001).

The selection of reference genes to study caste development in the honeybee is challenging, as queen and worker larvae develop at different rates (Stabe 1930) making it difficult to identify genes with stable expression. Two studies have investigated suitable reference genes for the honeybee (Lourenco et al. 2008; Scharlaken et al. 2008). Lourenco et al. (2008) investigated the expression of four candidate reference genes in worker larvae, pupae, adults treated with juvenile hormone and several tissues of adult queens. Scharlaken et al. (2008) looked at the expression of 11 reference genes in the heads of newly emerged workers after a bacterial challenge. Neither of these studies investigated whether their candidate genes had stable expression between castes.

Here, we identify, in a non-baised way, candidate reference genes based on microarray analysis of gene expression throughout queen and worker larval development. The stability of ten candidate reference genes identified in the microarray analysis was compared to five genes previously published in the literature as reference genes for insects. The stability of the expression of these genes was analysed during larval development, in each caste, to identify appropriate reference genes for studies of gene expression during larval caste development in honeybees.

\section{MATERIALS AND METHODS}

\subsection{Sample collection}

Matched queen and worker larvae were collected at six time points throughout larval development $(6,12,36$, 60,84 and $108 \mathrm{~h}$ post hatching). These samples were generated by caging a queen for several hours to ensure all eggs laid were of a similar age. As these eggs began hatching, queen samples were generated by grafting larvae into queen cells and placing them in a queenless hive where they would receive royal jelly. Worker larvae were placed in another hive where they would receive worker jelly and subsequently develop as workers. Larvae were collected at each time point in cryovials using paintbrushes and immediately frozen in liquid nitrogen. Five to six biological replicates of each time point were collected for use in array and RT-qPCR analysis

\subsection{RNA extraction and cDNA synthesis}

Total RNA was extracted from larval samples using TRIZOL $^{\circledR}$ (Invitrogen). RNA was further purified using RNeasy columns (Qiagen). RNA concentration and purity was measured using a NanoDrop ND-1000 spectrophotometer. RNA integrity was determined on a $1 \%$ agarose gel using gel electrophoresis. One microgramme of RNA from each sample was used to make cDNA using Superscript ${ }^{\circledR}$ VILO $^{\text {TM }}$ (contains random primers) according to manufacturer's instructions.

\subsection{Reference gene selection and primer design}

Candidate reference genes were selected from data generated by a microarray study designed to investigate gene expression in queen and worker larvae throughout larval development (Cameron, Duncan 
and Dearden, unpubl. data). GeneSpring GX 10 software was used to select genes with log normalised expression values close to one for all six time points. Genes that met these criteria $(n=65)$ were further ranked using GeNorm (original version) (Vandesompele et al. 2002) and NormFinder (Andersen et al. 2004) algorithms. The top eight candidate genes were selected from these analyses. We also included two genes that had previously been used as reference genes in our laboratory to confirm changes in gene expression during caste development, awd and $R p L 12$. In order to compare the expression stability of genes selected from the microarrays with reference genes previously published in insects, we selected 26 candidate reference genes from the literature. The gene expression values for these literature genes were determined from the microarray study and they were also ranked by GeNorm and NormFinder. The top five genes were selected to represent the literature genes.

Primers were designed for each gene using Primer 3 (Rozen et al. 1999) aiming to produce amplification efficiencies between 1.9 and 2.1, considered to be the optimal range for qPCR assays (Taylor et al. 2010). Primer sets used for each gene are provided in Supplementary Table I.

Primer efficiencies were first tested using the 84$\mathrm{h}$ queen sample. Primer performance was analysed in the non-diluted sample and across four dilutions $(1 / 10$, $1 / 100,1 / 1000$ and $1 / 10,000$ ).

In addition to the 15 candidate reference genes, primers were also designed for two genes (Catalase and $L O C 100577342)$ identified by microarray analysis (Cameron, Duncan and Dearden, unpublished data) as differentially expressed between queen and worker stage-four larvae.

\subsection{Quantitative PCR}

Quantitative PCR was performed using a LightCycler 480 (Roche). At each of the six time points expression of the 15 candidate reference genes was investigated in three independent queen and worker samples (each sample contained RNA pooled from 20 larvae at $6 \mathrm{~h}$ and five larvae from each of the remaining time points). Each sample was analysed in duplicate, and a negative control was included for each primer set. cDNA for amplification was diluted $1 / 10$.
The PCR programme used consisted of a 5-min initial denaturation at $95{ }^{\circ} \mathrm{C}$, followed by 50 cycles $95{ }^{\circ} \mathrm{C}, 1 \mathrm{~min}, 60^{\circ} \mathrm{C}, 5 \mathrm{~s}, 72{ }^{\circ} \mathrm{C}, 8 \mathrm{~s}$. On completion a melt curve analysis was carried out by incrementally raising the temperature to $95{ }^{\circ} \mathrm{C}$ through $0.5{ }^{\circ} \mathrm{C}$ increments for $30 \mathrm{~s}$ before dropping to $65^{\circ} \mathrm{C}$ for $5 \mathrm{~s}$. The integrity of all products was checked using agrose gel electrophoresis and all products were sequenced to ensure the correct product was amplified.

\subsection{Data analysis}

Quantification cycle $(\mathrm{Cq})$ values were analysed using four algorithms. GeNorm (original version) uses relative expression levels (Vandesompele et al. 2002). GeNorm ${ }^{\text {PLUS }}$ uses raw Cq values as input and calculates relative expression levels for genes using a modified Pffafl method that allows for the use of multiple reference genes (Hellemans et al. 2007). This modified Pffafl method takes amplification efficiency into account (Hellemans et al. 2007). GeNorm relies on the principle that expression ratios for two reference genes should remain constant across all samples measured. The output of GeNorm is an $M$ value which represents the average pairwise variation of a reference gene with all other candidate reference genes.

NormFinder determines inter and intra group variation of expression values for each gene (Andersen et al. 2004), using expression values. The expression values for this analysis were calculated from $\mathrm{Cq}$ values using the Pfaffl method which takes amplification efficiency into account (Pfaffl 2001). NormFinder produces a stability value for each gene which represents variation in expression across samples and between groups.

Bestkeeper identifies the most stable reference genes (Pfaffl et al. 2004) using raw Cq values and amplification efficiencies to determine the most stable reference genes. These stable reference genes are then used to generate the Bestkeeper index. A pairwise correlation analysis is performed between each combination of genes and the Bestkeeper index. From this analysis, the reference genes can be ranked from most stable to least stable. For further information on the calculations used by Bestkeeper, see Pfaffl et al. (2004). 


\subsection{Statistical analyses}

Expression values were calculated from $\mathrm{Cq}$ values using the Pfaffl method (Pfaffl 2001). Samples were normalised to the lowest average $\mathrm{Cq}$ value (calibrator) by subtracting the average $\mathrm{Cq}$ of each sample from the calibrator. This value to the power of the efficiency provides the expression value for the sample. The expression values for the target genes were then normalised to the expression values of the two sets of reference genes.

A one-way ANOVA was performed in SPSS with raw $\mathrm{Cq}$ values to determine if there was any variation in transcript levels between queen $n=(18)$ and worker $(n=$ 18) samples. In addition, a two-way ANOVA was performed with Fisher's least significant difference (LSD) post hoc test to determine if there was a difference between queen and worker samples at specific time points. $P$ values $<0.05$ were considered to be significant.

The Shapiro-Wilk test was used to determine if the residuals from the ANOVA followed a normal distribution. The residuals in all but three genes (RpL19, LOC4111024 and pontin) were found to follow a normal distribtuion.

\section{RESULTS}

\subsection{Choice of candidate genes}

Fifteen candidate genes were selected to identify stable reference genes for studying caste development. Ten of these were selected from microarray analysis and five from the literature. Table I lists the genes selected from the literature. All genes were selected based on ranking of their expression values with Normfinder and GeNorm based on microarray data.

The genes in Table I had been previously investigated as reference genes in honeybees, silk moth (Bombyx mori) (Wang et al. 2008) or springtails (Folsomia candida / Orchesella cincta) (de Boer et al. 2009). Table II shows the details the genes identified as having stable expression throughout larval development between queens and workers based on microarray analysis.
There were several primer sets that had efficiencies that fell outside the optimal range of 1.9 to 2.1; $R p S 18$ had an efficiency of $1.89 a w d, R p L 12$ and pontin had efficiencies over 2.1. As the efficiencies were outside the optimal range the primer sets for these genes may have not been ideal.

\subsection{Transcript abundance across larval development}

The expression of the 15 candidate reference genes was examined between queen and worker larval samples at six time points throughout development. Figure 1 indicates the range of sample (Cq) values obtained for each gene in queen (white boxes) and worker (grey boxes) samples. This box and whisker plot represents the $\mathrm{Cq}$ values across all six time points in queens and workers for each gene.

A one-way ANOVA was used to determine if any of the genes showed a significant difference in $\mathrm{Cq}$ values between queens and workers. Two genes had significant $P$ values $(<0.05$, indicated by asterisks in Figure 1), RpL10 and LOC552572. A two-way ANOVA and LSD post hoc test was then used to determine at which time points there was a significant difference in $\mathrm{Cq}$ values between queens and workers. Supplementary Figure 1 shows the box and whisker plots for $\mathrm{Cq}$ values in queens and workers at each time point. There were several genes that showed a significant difference $(P<$ 0.05 , indicated by asterisks) in $\mathrm{Cq}$ values between queens and workers at specific time points (LOC408353, Ndufa8, RpL10, Gapdh, LOC552572, RpL12, LOC408353 and pontin) .

As the Shapiro-Wilk test indicated that the residuals from RpL19, LOC4111024 and pontin do not follow a normal distribution, an ANOVA may result in type one errors where the null hypothesis is incorrectly rejected (Lix et al. 1996). Fortunately it has been shown that the false-positive rate is only mildly affected by violation of this assumption (Glass et al. 1972; Lix et al. 1996). Furthermore, only pontin was affected by this type of error as it is the only gene with a significant difference in expression between queens and workers (at $36 \mathrm{~h}$ ). 
Table I. Candidate reference genes selected from the literature.

\begin{tabular}{|c|c|c|c|c|c|c|c|}
\hline $\begin{array}{l}\text { Gene } \\
\text { symbol }\end{array}$ & Gene name & $\begin{array}{l}\text { RefSeq mRNA } \\
\text { identifier }\end{array}$ & Reference & Organism & $\begin{array}{l}\text { Amplicon } \\
\text { size }\end{array}$ & Efficiency & $R^{2}$ value \\
\hline$R p L 19$ & $\begin{array}{l}\text { Ribosomal } \\
\quad \text { protein L19 }\end{array}$ & XM_001119828.2 & $\begin{array}{l}\text { (Wang et al. } \\
\text { 2008) }\end{array}$ & $\begin{array}{c}\text { Bombyx } \\
\text { mori }\end{array}$ & 99 & 2.011 & 1 \\
\hline$R p S 18$ & $\begin{array}{l}\text { Ribosomal } \\
\text { protein S18 }\end{array}$ & XM_625101.3 & $\begin{array}{l}\text { (Scharlaken } \\
\text { et al. 2008) }\end{array}$ & $\begin{array}{l}\text { Apis } \\
\quad \text { mellifera }\end{array}$ & 118 & 1.887 & 0.9735 \\
\hline Gapdh & $\begin{array}{l}\text { Glyceraldehyde } \\
\text { 3-phosphate } \\
\text { dehydrogenase }\end{array}$ & XM_393605.4 & $\begin{array}{l}\text { (Scharlaken } \\
\text { et al. 2008) }\end{array}$ & $\begin{array}{l}\text { Apis } \\
\quad \text { mellifera }\end{array}$ & 74 & 2.066 & 0.9996 \\
\hline $\begin{array}{r}\text { LOC55 } \\
2572\end{array}$ & $\begin{array}{l}\text { Eukaryotic } \\
\text { translation } \\
\text { initiation } \\
\text { factor } 5 \text { A-like }\end{array}$ & XM_624948.3 & $\begin{array}{l}\text { (de Boer et } \\
\text { al. 2009) }\end{array}$ & $\begin{array}{l}\text { Folsomia } \\
\text { candida / } \\
\text { Orchesella } \\
\text { cincta }\end{array}$ & 90 & 2.021 & 0.9994 \\
\hline$R p L 27 A$ & $\begin{array}{l}\text { Ribosomal } \\
\quad \text { protein L27A }\end{array}$ & XM_624693.3 & $\begin{array}{l}\text { (Wang et al. } \\
\text { 2008) }\end{array}$ & $\begin{array}{c}\text { Bombyx } \\
\text { mori }\end{array}$ & 147 & 2.009 & 1 \\
\hline
\end{tabular}

\subsection{Stability analysis}

The expression values of our potential reference genes were analysed with the four different programmes to determine a stability ranking (Table III). Each gene was given an overall ranking based on how stable its expression remained between queen and worker larvae as determiend by each of the programmes.

RpS18, LOC408353, pontin, LOC411024 and Gapdh were not included in the Bestkeeper analysis as four of these genes had SDs over one, and were thus removed from the analysis as suggested by (Pfaffl et al. 2004). Gapdh had a SD below one but it was not included in the analysis as a limit of ten genes can be analysed at once with Bestkeeper, and Gapdh had the highest $\mathrm{SD}$ of the remaining genes so was unlikely to be highly ranked. The Bestkeeper ranking was based on the correlation between the Bestkeeper index and the candidate reference gene (r). Genes that have $r$ values close to 1.0 represent the most stable genes.

Table II. Candidate reference genes selected from microarray analysis of caste development.

Gene symbol Gene name
RefSeq mRNA Amplicon Efficiency $R^{2}$ value identifier size

\begin{tabular}{|c|c|c|c|c|c|}
\hline LOC727012 & Reactive oxygen species modulator 1-like & XM_003250796.1 & 121 & 1.914 & 0.9999 \\
\hline Ndufa38 & NADH dehydrogenase (ubiquinone) & XM_392983.4 & 78 & 2.01 & 0.9987 \\
\hline LOC411024 & $\begin{array}{l}\text { DDB1- and CUL4-associated factor } \\
\text { 13-like }\end{array}$ & XM_394497.4 & 128 & 2.017 & 0.9999 \\
\hline$R p L 10$ & $60 \mathrm{~S}$ ribosomal protein $\mathrm{L} 10$ & XM_393092.4 & 130 & 1.953 & 0.9997 \\
\hline Pros 54 & Proteasome $54 k D$ subunit & XM_393112.4 & 100 & 1.928 & 0.9996 \\
\hline U2af38 & $\begin{array}{l}\text { U2 small nuclear riboprotein auxiliary } \\
\text { factor } 38\end{array}$ & XM_397281.4 & 138 & 2.037 & 0.9997 \\
\hline awd & Nucleoside diphosphate kinase awd & XM_393351.4 & 142 & 2.185 & 1 \\
\hline RpL12 & Ribosomal protein L12 & XM_624693.3 & 126 & 2.106 & 0.9997 \\
\hline LOC408353 & Proteasome subunit beta type-7-like & XM_391905.4 & 108 & 1.964 & 0.9992 \\
\hline pontin & Pontin encoding gene & XM_393051.4 & 90 & 2.193 & 0.9942 \\
\hline
\end{tabular}




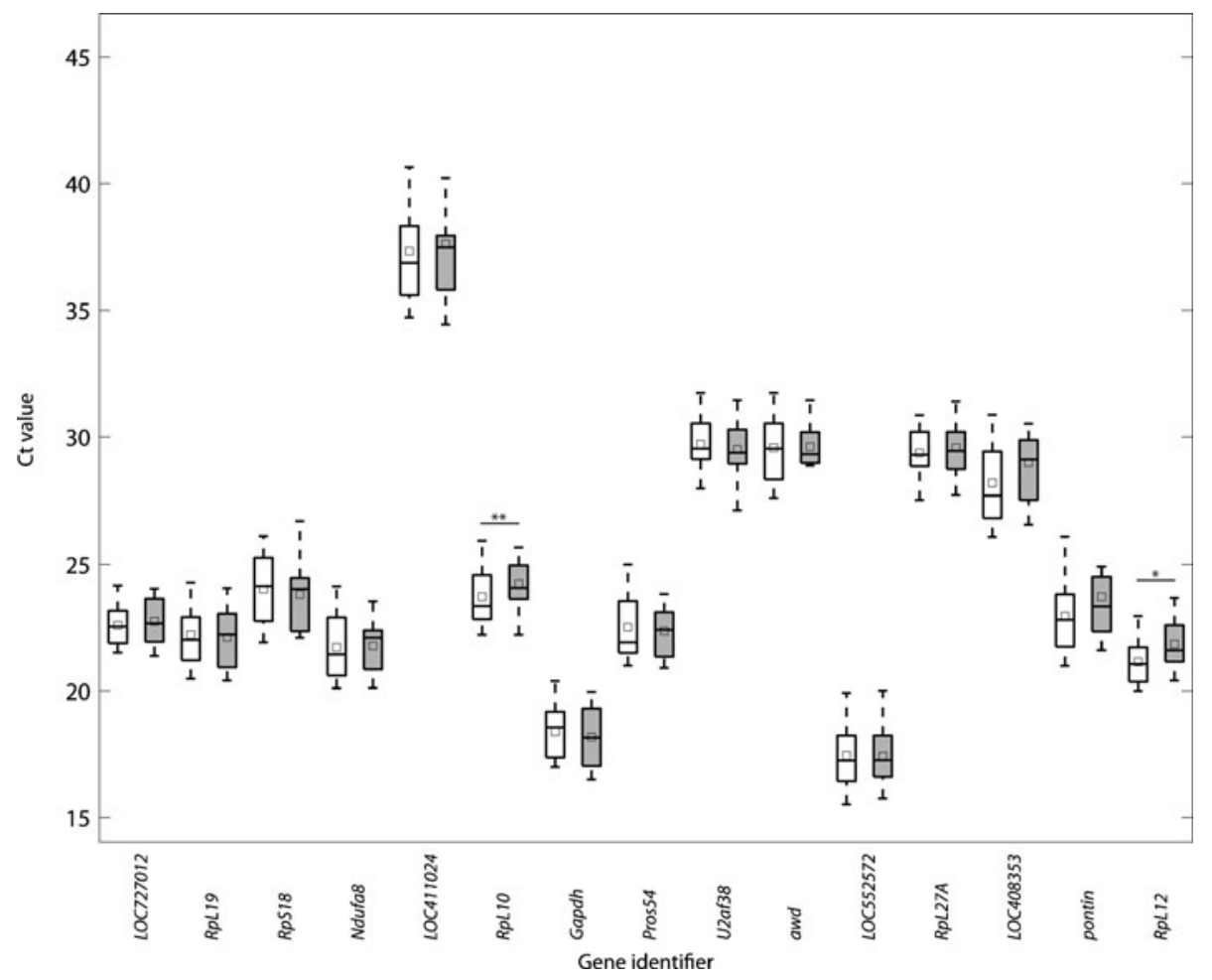

Figure 1. Expression of the 15 candidate reference genes in queens and workers. Values are given as cycle threshold values (Cq). The boxes represent the lower and upper quartiles with the median represented by a horizontal line. The mean values are represented by the smaller boxes. The whiskers represent the maximum and minimum $\mathrm{Cq}$ values for each sample. For each gene the expression values for queens are represented in white and workers are represented in grey. Genes that had significantly different expression between queens and workers are marked with asterisks, * indicates a $P$ value $<0.05$ and $* *$ indicates a $P$ value $<0.01$.

GeNorm suggests the use of two reference genes Ndufa8 and Pros54, while GeNorm ${ }^{\text {PLUS }}$ suggests that three reference genes (Ndufa8, Pros54 and RpL19) are required to achieve accurate normalisation. The number of recommended reference genes is based on the pairwise variation ( $V$ value) between reference genes. A $V$ value cutoff of 0.15 has been proposed to give the ideal number of reference genes (Vandesompele et al. 2002; Hellemans et al. 2007).

Only two genes were selected from this analysis rather than three. RpL19 was considered to be a good reference gene by GeNorm, however, although it was ranked third overall it was ranked fourth by Bestkeeper and Norm-
Finder. It was therefore concluded that it was likely to add little to the analysis that could not be achieved with the use of two reference genes (Ndufa8 and Pros54). It is, however, possible that in some situations use of all three genes may be valuable.

The two top ranking genes were identified from the microarray analysis rather than candidates previously published in the literature. The two reference genes that had been previously used in our laboratory ranked relatively poorly ( $a w d$ and RpL12 were ranked 9th and 13th).

The top two candidate reference genes were Ndufas and Pros54. The Drosophila ortholog of Ndufa8 is CG3683, which encodes a component of complex one of the mitochondrial electron 
Table III. Ranking of candidate reference genes

\begin{tabular}{llccccc}
\hline Gene identifier & Source & $\begin{array}{l}\text { Bestkeeper } \\
(R \text { value })\end{array}$ & $\begin{array}{l}\text { GeNorm } \\
(M \text { value })\end{array}$ & $\begin{array}{l}\text { GeNormPLUS } \\
(M \text { value })\end{array}$ & $\begin{array}{l}\text { NormFinder } \\
\text { (stability value })\end{array}$ & Overall rank \\
\hline Ndufa8 & $\mathrm{M}$ & $0.951(1)$ & $0.31(1)$ & $0.41(2)$ & $0.0888(1)$ & 1 \\
Pros54 & $\mathrm{M}$ & $0.942(2)$ & $0.31(1)$ & $0.403(1)$ & $0.1167(3)$ & 2 \\
RpL19 & $\mathrm{L}$ & $0.898(4)$ & $0.369(3)$ & $0.434(3)$ & $0.1216(4)$ & 3 \\
LOC552572 & $\mathrm{L}$ & $0.920(3)$ & $0.46(5)$ & $0.578(6)$ & $0.0956(2)$ & 4 \\
LOC727012 & $\mathrm{M}$ & $0.896(5)$ & $0.421(4)$ & $0.542(5)$ & $0.1237(5)$ & 5 \\
RpL10 & $\mathrm{M}$ & $0.841(6)$ & $0.585(7)$ & $0.694(9)$ & $0.1402(7)$ & 6 \\
Gapdh & $\mathrm{L}$ & $\mathrm{NaN}(11)$ & $0.512(6)$ & $0.628(7)$ & $0.1531(9)$ & 7 \\
RpS18 & $\mathrm{M}$ & $\mathrm{NaN}(11)$ & $0.847(11)$ & $0.49(4)$ & $0.1599(10)$ & 8 \\
pontin & $\mathrm{L}$ & $\mathrm{NaN}(11)$ & $0.648(8)$ & $0.777(11)$ & $0.1334(6)$ & 8 \\
RpL12 & $\mathrm{P}$ & $0.434(10)$ & $0.711(9)$ & $0.833(12)$ & $0.1509(8)$ & 9 \\
U2af38 & $\mathrm{M}$ & $0.640(9)$ & $0.775(10)$ & $0.735(10)$ & $0.1674(12)$ & 10 \\
RpL27A & $\mathrm{L}$ & $0.831(7)$ & $1.169(14)$ & $0.667(8)$ & $0.1764(13)$ & 11 \\
LOC411024 & $\mathrm{M}$ & $\mathrm{NaN}(11)$ & $1.024(13)$ & $0.965(13)$ & $0.1604(11)$ & 12 \\
awd & $\mathrm{P}$ & $0.768(8)$ & $0.904(12)$ & $1.133(14)$ & $0.2051(15)$ & 13 \\
LOC408353 & $\mathrm{M}$ & $\mathrm{NaN}(11)$ & $1.328(15)$ & $1.371(15)$ & $0.1819(14)$ & 14 \\
\hline
\end{tabular}

$\mathrm{NaN}$ indicates genes that were excluded from the Bestkeeper analysis due to high standard deviations as only ten genes can be analysed at one time

Rankings for each gene indicated in brackets and these rankings were used to produce the overall rank value

$M$ genes identified from microarray analysis, $P$ genes previously used in the laboratory, $L$ genes published in the literature

transport chain (Sardiello et al. 2003). The Drosophila ortholog of Pros54 is CG7619, encoding a subunit of the $26 \mathrm{~S}$ proteosome (Holzl et al. 2000).

\subsection{Sensitivity analysis of selected reference genes in RT-qPCR analysis}

To determine if our two top candidate genes (Ndufa 8 and Pros54) provided more sensitivity to detect differences in transcript abundance of genes of interest as compared to two previously used reference genes (RpL12 and awd, ranked 9 th and 13th, respectively), we used both sets of genes to normalise the expression of two target genes. The two target genes (Catalase and LOC100577342) were identified as being differentially expressed between queen and worker larvae at $84 \mathrm{~h}$ using microarray analysis.

The transcript abundance of these two target genes was measured in three 84 -h queen and worker RNA samples and then normalised with each of the two sets of reference genes. Figure 2 indicates the relative expression of these two target genes when normalised to each set of reference genes.

Using the genes identified as the most stable reference genes in this study, Ndufa 8 and Pros 54, to normalise the target genes reveals that there is a significant difference in expression for both target genes between queens and workers, consistent with the microarray data. However, using lower ranked reference genes ( $R p L 12$ and $a w d$ ) we do not detect a significant difference between queen and worker samples.

\section{DISCUSSION}

Understanding the molecular processes that underly caste development is an important research objective; however, in order to do this, we must be able to accurately and sensitively 


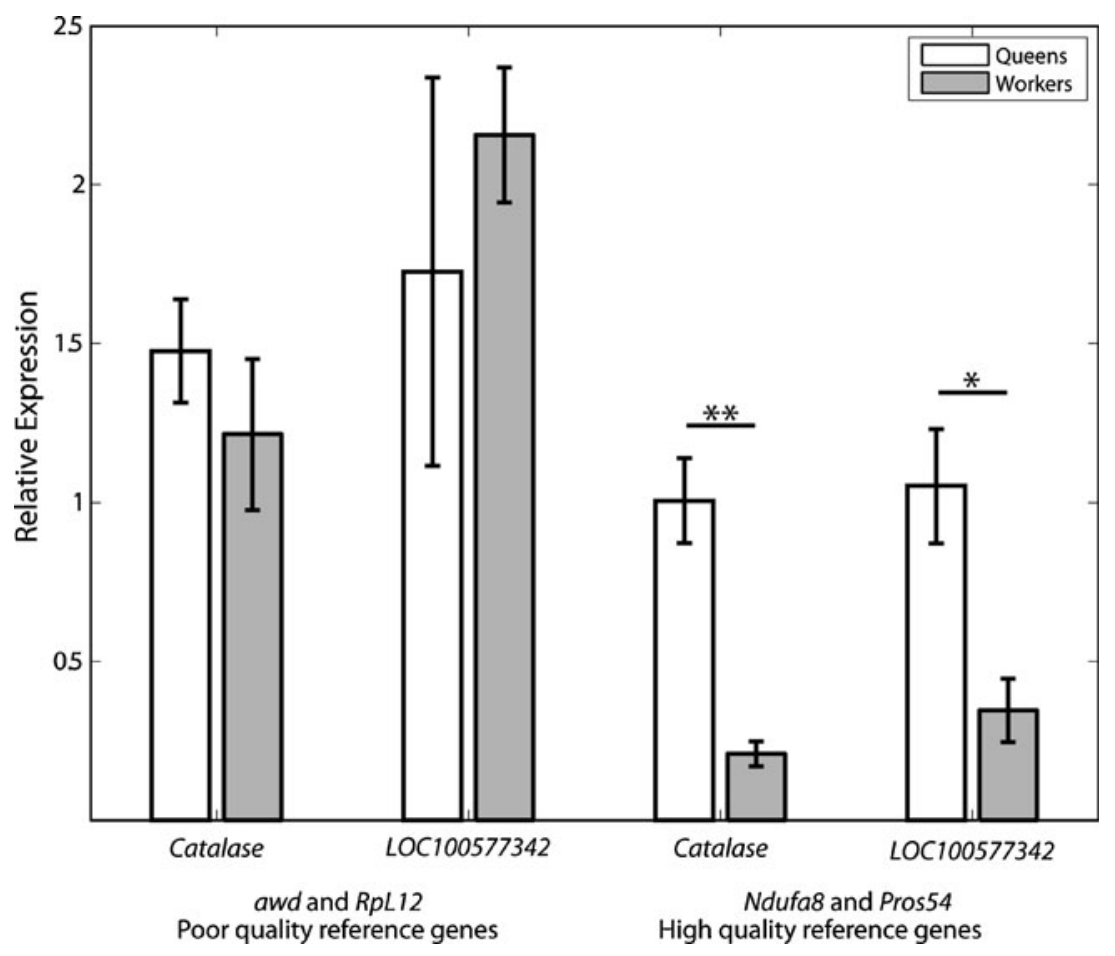

Figure 2. Normalisation of two target genes with the poor quality reference genes and the best ranked reference genes using the Pfaffl method. A $t$ test was used to determine significant differences between queen and worker samples. $P$ values $<0.05$ are indicated by a single asterisk and $P$ values $<0.01$ by two asterisks.

monitor differences in gene expression. This study has identified two reference genes (Ndufas and Pros54) that remain stable throughout the majority of larval development in queen and worker larvae and offer considerable improvement over genes that have been traditionally used as reference genes. These reference genes also have better stability values than honeybee reference genes identified in two previous studies (Lourenco et al. 2008; Scharlaken et al. 2008).

Ndufa 8 and Pros54 were identified as the most stable reference genes in this study. These two genes were also found to have stable gene expression at several larval stages based on the gene expression data generated by Barchuk et al. (2007). Data from the same study indicates that these genes do not show fluctuations in expression in response to treatment with juvenile hormone (Barchuk et al. 2007), making them useful for gene expression studies of caste development.

Although Ndufas is the top-ranked reference gene, there is evidence that it is differentially expressed between queen and worker larvae at $108 \mathrm{~h}$ (Supplementary Figure 1). Therefore this gene may not be able to accurately detect changes in gene expression at $108 \mathrm{~h}$. During the later stages of larval development, it is likely to be difficult to find genes that have consistent expression between the two castes as they are developing at different rates (Stabe 1930). The other gene (Pros54) does not show differential expression at $108 \mathrm{~h}$ and thus is an excellent reference at $108 \mathrm{~h}$.

The stability of some candidate reference genes (RpS18, RpL12 and pontin) may have been under-estimated due to primers that had efficiencies outside the recommended range. These reference genes may actually be more stability expressed than indicated in the ranking 
system, but require new primer designs to be useful.

The best evidence for the quality of $N d u f a 8$ and Pros54 comes by comparing them to two poorquality reference genes. Normalisation of the target genes to lower ranked reference genes was unable to identify a significant difference in expression between queens and workers while Ndufa 8 and Pros 54 did, consistent with previous results.

The top two candidate genes identified in this analysis were identified from microarrays rather than from the literature. This reinforces the idea that the most stable reference genes may be those that do not have well-known housekeeping roles. The Drosophila ortholog of Ndufa 8 encodes a protein component of complex one in the electron transport chain (Sardiello et al. 2003) The Drosophila ortholog of Pros54 encodes a component of the $26 \mathrm{~S}$ proteosome (Holzl et al. 2000). Neither of these genes would have been considered 'traditional' reference genes.

There are no previous studies of reference genes suitable to investigate gene expression during caste development, yet there are a number of publications comparing gene expression between queens and workers during larval development using RT-qPCR (Wheeler et al. 2006; Patel et al. 2007; Kucharski et al. 2008; Azevedo et al. 2011; Mutti et al. 2011; Wolschin et al. 2011). The identification of these two reference genes will benefit future studies of honeybee caste development by providing stability in gene expression analyses and, if used widely, comparability between analyses from different labs.

\section{ACKNOWLEDGMENTS}

RCC would like to thank Caroline Walker for advice and discussion that led to the development of this study. All authors would like to thank Frans Laas and Bettabees for help obtaining larval samples. This work was funded by the Royal Society of New Zealand Marsden Fund Grant (UOO0707) to P.K.D.

Open Access This article is distributed under the terms of the Creative Commons Attribution License which permits any use, distribution, and reproduction in any medium, provided the original author(s) and the source are credited.
Gènes de référence stables pour mesurer l'abondance de transcrits chez les larves d'abeilles durant le développement des castes

Développement/ caste/ développement larvaire/ expression génique/ PCR quantitative

Stabile Referenzgene für quantitative Transkriptbestimmungen in der Kastenentwicklung von Honigbienenlarven

quantitative RT-PCR/ Referenzgene/ Kastenentwicklung

\section{REFERENCES}

Andersen, C.L., Jensen, J.L., Orntoft, T.F. (2004) Normalization of real-time quantitative reverse transcription-PCR data: a model-based variance estimation approach to identify genes suited for normalization, applied to bladder and colon cancer data sets. Cancer Res. 64(15), 5245-5250

Azevedo, S.V., Caranton, O.A.M., de Oliveira, T.L., Hartfelder, K. (2011) Differential expression of hypoxia pathway genes in honey bee (Apis mellifera L.) caste development. J. Insect Physiol. 57(1), 38-45

Barchuk, A.R., Cristino, A.S., Kucharski, R., Costa, L.F., Simoes, Z.L., Maleszka, R. (2007) Molecular determinants of caste differentiation in the highly eusocial honeybee Apis mellifera. BMC Dev. Biol. 7, 70

Bustin, S.A., Benes, V., Garson, J.A., Hellemans, J., Huggett, J., et al. (2009) The MIQE guidelines: minimum information for publication of quantitative real-time PCR experiments. Clin. Chem. 55(4), 611622

Chen, X., Hu, Y., Zheng, H., Cao, L., Niu, D., Yu, D., Sun, Y., Hu, S., Hu, F. (2012) Transcriptome comparison between honey bee queen- and workerdestined larvae. Insect. Biochem. Mol. Biol. 42(9), 665-673

Corona, M., Estrada, E., Zurita, M. (1999) Differential expression of mitochondrial genes between queens and workers during caste determination in the honeybee Apis mellifera. J. Exp. Biol. 202(Pt 8), 929-938

de Azevedo, S.V., Hartfelder, K. (2008) The insulin signaling pathway in honey bee (Apis mellifera) caste development - differential expression of insulin-like peptides and insulin receptors in queen and worker larvae. J. Insect Physiol. 54(6), 10641071

de Boer, M., de Boer, T., Marien, J., Timmermans, M., Nota, B., van Straalen, N., Ellers, J., Roelofs, D. (2009) Reference genes for QRT-PCR tested under various stress conditions in Folsomia candida and Orchesella cincta (Insecta, Collembola). BMC Mol. Biol. 10(1), 54 
Evans, J.D., Wheeler, D.E. (1999) Differential gene expression between developing queens and workers in the honey bee. Apis mellifera. Proc. Natl. Acad. Sci. U S A 96(10), 5575-5580

Evans, J.D., Wheeler, D.E. (2001) Expression profiles during honeybee caste determination. Genome Biol. 2(1), RESEARCH0001

Glass, G.V., Peckham, P.D., Sanders, J.R. (1972) Consequences of Failure to Meet Assumptions Underlying the Fixed Effects Analyses of Variance and Covariance. Rev. Educ. Res. 42(3), 237-288

Hellemans, J., Mortier, G., De Paepe, A., Speleman, F., Vandesompele, J. (2007) qBase relative quantification framework and software for management and automated analysis of real-time quantitative PCR data. Genome Biol. 8(2), R19

Holzl, H., Kapelari, B., Kellermann, J., Seemuller, E., Sumegi, M., et al. (2000) The regulatory complex of Drosophila melanogaster $26 \mathrm{~S}$ proteasomes: subunit composition and localization of a deubiquitylating enzyme. J. Cell Biol. 150(1), 119-129

Humann, F.C., Hartfelder, K. (2011) Representational Difference Analysis (RDA) reveals differential expression of conserved as well as novel genes during caste-specific development of the honey bee (Apis mellifera L.) ovary. Insect Biochem. Mol. Biol. 41 (8), 602-612

Kucharski, R., Maleszka, J., Foret, S., Maleszka, R. (2008) Nutritional control of reproductive status in honeybees via DNA methylation. Science 319 (5871), 1827-1830

Lix, L.M., Keselman, J.C., Keselman, H.J. (1996) Consequences of Assumption Violations Revisited: a Quantitative Review of Alternatives to the OneWay Analysis of Variance F Test. Rev. Educ. Res. 66(4), 579-619

Lourenco, A., Mackert, A., Cristino, A., Simões, Z. (2008) Validation of reference genes for gene expression studies in the honey bee, Apis mellifera, by quantitative real-time RT-PCR. Apidologie 39(3), 372-385

Mutti, N.S., Wang, Y., Kaftanoglu, O., Amdam, G.V. (2011) Honey Bee PTEN Description, Developmental Knockdown, and Tissue-Specific Expression of Splice-Variants Correlated with Alternative Social Phenotypes. PLoS One 6(7), e22195

Okoniewski, M., Miller, C. (2006) Hybridization interactions between probesets in short oligo microarrays lead to spurious correlations. BMC Bioinforma. 7 (1), 276

Patel, A., Fondrk, M.K., Kaftanoglu, O., Emore, C., Hunt, G., Frederick, K., Amdam, G.V. (2007) The Making of a Queen: TOR Pathway Is a Key Player in Diphenic Caste Development. PLoS One 2(6), e509
Pfaffl, M.W. (2001) A new mathematical model for relative quantification in real-time RT-PCR. Nucleic Acids Res. 29(9)

Pfaffl, M.W., Tichopad, A., Prgomet, C., Neuvians, T.P. (2004) Determination of stable housekeeping genes, differentially regulated target genes and sample integrity: BestKeeper-Excel-based tool using pairwise correlations. Biotechnol. Lett. 26(6), 509-515

Rozen, S., Skaletsky, H., Misener, S., Krawetz, S.A. (1999) Primer3 on the WWW for General Users and for Biologist Programmers. In: Walker, J.M. (ed.) Bioinformatics Methods and Protocols, pp. 365386. Humana Press, New York

Sardiello, M., Licciulli, F., Catalano, D., Attimonelli, M., Caggese, C. (2003) MitoDrome: a database of Drosophila melanogaster nuclear genes encoding proteins targeted to the mitochondrion. Nucleic Acids Res. 31(1), 322-324

Scharlaken, B., de Graaf, D.C., Goossens, K., Brunain, M., Peelman, L.J., Jacobs, F.J. (2008) Reference gene selection for insect expression studies using quantitative real-time PCR: the head of the honeybee, Apis mellifera, after a bacterial challange. J. Insect Sci. 8, 33

Severson, D.W., Williamson, J.L., Aiken, J.M. (1989) Caste-Specific Transcription in the Female Honey Bee. Insect Biochem. 19(2), 215-220

Stabe, H. (1930) The rate of growth of worker, drone and queen larvae of the honeybee Apis mellifera Linn. J. Econ. Entomol. 23(2), 447-453

Taylor, S., Wakem, M., Dijkman, G., Alsarraj, M., Nguyen, M. (2010) A practical approach to RTqPCR - publishing data that conform to the MIQE guidelines. Methods. 50(4), S1-S5

Valasek, M.A., Repa, J.J. (2005) The power of real-time PCR. Adv. Physiol. Educ. 29(3), 151-159

Vandesompele, J., De Preter, K., Pattyn, F., Poppe, B., Van Roy, N., De Paepe, A., Speleman, F. (2002) Accurate normalization of real-time quantitative RTPCR data by geometric averaging of multiple internal control genes. Genome Biol. 3(7), RESEARCH0034

Wang, G.-H., Xia, Q.-Y., Cheng, D.-J., Duan, J., Zhao, P., Chen, J., Zhu, L. (2008) Reference genes identified in the silkworm Bombyx mori during metamorphism based on oligonucleotide microarray and confirmed by qRT-PCR. Insect Sci. 15(5), 405-413

Wheeler, D.E., Buck, N., Evans, J.D. (2006) Expression of insulin pathway genes during the period of caste determination in the honey bee. Apis mellifera. Insect Mol. Biol. 15(5), 597-602

Wolschin, F., Mutti, N.S., Amdam, G.V. (2011) Insulin receptor substrate influences female caste development in honeybees. Biol. Lett. 7(1), 112-115 